\title{
Performance, Immune, and Carcass Characteristics of Broiler Chickens as Affected by Thyme and Licorice or Enzyme Supplemented Diets
}

\author{
Majid Kalantar' ${ }^{1}$, Seyed Mahdi Hosseini2 ${ }^{*}$, Liguo Yang ${ }^{2}$, Sayed Haider Abbas Raza ${ }^{3}$, \\ Linsheng Gui ${ }^{3}$, Mostafa Rezaie ${ }^{4}$, Mahdi Khojastekey', Dawei Wei ${ }^{3}$, Rajwali Khan ${ }^{3}$, \\ Sulthattin Yasar5, Shahid Faraz Syed6, Allah Bux Kachiwal7, \\ Mohamed Elkhairey33, Qijing Lei6, Rameez Raja Kaleri'7, \\ Ayman Hassan Abd El-Aziz ${ }^{8}$ \\ ${ }^{1}$ Animal Science Department, Agricultural Research Center of Qom, Qom, Iran \\ ${ }^{2}$ The Key Lab of Agricultural Animal Genetics, Breeding and Reproduction of the Ministry of Education, College of Animal \\ Science and Technology, Huazhong Agricultural University, Wuhan, China \\ ${ }^{3}$ College of Animal Science and Technology, Northwest A\&F University, Yangling, China \\ ${ }^{4}$ Department of Animal Science, Saveh Branch, Islamic Azad University of Saveh, Saveh, Iran \\ ${ }^{5}$ College of Animal Science, Süleyman Demirel University, Isparta, Turkey \\ ${ }^{6}$ College of Veterinary Medicine, Northwest A\&F University, Yangling, China \\ ${ }^{7}$ Faculty of Animal Husbandry \& Veterinary Sciences, Sindh Agriculture University, Tandojam, Pakistan \\ ${ }^{8}$ Faculty of Veterinary Medicine, Damanhour University, Damanhūr, Egypt \\ Email: ${ }^{*}$ Mehdi_hoseini10@yahoo.com
}

How to cite this paper: Kalantar, M., Hosseini, S.M., Yang, L.G., Raza, S.H.A., Gui, L.S., Rezaie, M., Khojastekey, M., Wei, D.W., Khan, R., Yasar, S., Syed, S.F., Kachiwal, A.B., Elkhairey, M., Lei, Q.J., Kaleri, R.R. and El-Aziz, A.H.A. (2017) Performance, Immune, and Carcass Characteristics of Broiler Chickens as Affected by Thyme and Licorice or Enzyme Supplemented Diets. Open Journal of Animal Sciences, 7, 105-109.

https://doi.org/10.4236/ojas.2017.72009

Received: November 30, 2016

Accepted: April 11, 2017

Published: April 17, 2017

\begin{abstract}
Numbers of 300 day-old broiler chickens through a CRD design with 5 treatments, 3 replicates and 20 chicks in each pen were used to evaluate the effect of thyme (T), licorice (L), thyme + licorice (TL), and enzyme supplemented (E) diets on performance, immune and carcass characteristics. According to the results, performance traits, immune indices, and carcass traits in herbal medicine and enzyme supplemented diets were improved significantly than control diet $(\mathrm{P}<0.05)$. Weight gain and FCR in $\mathrm{T}$ and $\mathrm{E}$ groups were significantly higher and lower than other groups respectively $(\mathrm{P}<0.05)$. Internal organs such as abdominal fat and liver weight as indicators of lipogenesis rate were decreased in T, L, and TL diets than control or E diet significantly $(\mathrm{P}<$ 0.05). Immune organs such as burse and spleen weight as indicators of immune situation were increased in TL diet than other treatments significantly $(\mathrm{P}<0.05)$. These findings indicated that thyme and licorice singly or in combination as organic herbal medicine can affect performance, carcass and immune characteristics. Also an improved immune organ such as burse or
\end{abstract}


Copyright (C) 2017 by authors and Scientific Research Publishing Inc. This work is licensed under the Creative Commons Attribution International License (CC BY 4.0).

http://creativecommons.org/licenses/by/4.0/ spleen in this study indicates that this herbal medicine can promote the immune situation and efficacy of health and livability.

\section{Keywords}

Broiler, Enzyme, Licorice, Thyme

\section{Introduction}

The use of antibiotic in poultry nutrition was banned from year of 2006 due to development of antibiotic resistant bacterial cerotype which is the most dangerous threat for global human population [1]. Search for alternatives to antibiotic resulted in safe materials with nature characteristics and mediated by intestinal micro flora such as medicinal plants and exogenous enzymes supplementations [2] [3]. Different medical plants have been used in recent years to improve growth, health and physiological aspects of poultry [4]. Dietary enzyme addition is one of the main strategies to achieve gut health through breakdown of large molecules inside the gut and reducing intestinal viscosity, prevention of bacterial fermentation and producing of injurious products via intestinal micro flora [3] [5].

Thyme (Thymus vulgaris) is an aromatic herb, no perennial and a member of mendacious family which has been reported to have anti-microbial, anti-viral, anti-coccidial, antioxidant and appetite inducing effect. The main active substance of thyme is thymol as phenolic component which commonly used as antibacterial material [6] [7].

Licorice (Glycyrrihiza galabra) is another aromatic herb, no perennial and a member of legominacae family which has been reported to have anti-microbial, anti-viral, anti-inflammatory, antioxidant and appetite inducing effect such as thyme. The main active substance of licorice is glycyrritinic acid and flavonoids as anti-inflammatory and antioxidant components [1] [8].

In this study as a main aim the effects of two dietary medicinal plants singly or in combination in comparison with exogenous enzyme supplemented diet were evaluated on growth, immune and carcass traits of broiler chickens.

\section{Materials and Methods}

An experiment was designed and number of 300 day-old broiler chickens through a CRD design with 5 treatments, 3 replicates and 20 chicks in each pen were used to evaluate the effect of thyme (T), licorice (L), thyme + licorice (TL), and enzyme supplemented (E) diets on performance, immune and carcass characteristics. The experimental traits were included feed intake, gain, and feed conversion ratio to assay the performance and carcass parts including breast, leg and carcass percentage to assay the carcass characteristics, and further were evaluated the internal organs such as burse and spleen to assay the immune situation. Treatments were included as follow: Control diet (corn-soy based diet 
without any additive), Thyme diet (control plus thyme powder), Licorice diet (control plus licorice powder), Mixed herbal medicine diet (control plus thyme and licorice powder equally), and Enzyme diet (control plus enzyme supplementation). Diets were designed as starter and grower based on NRC [9] recommendations. Feed and water were offered ad libitum in all period of experiment. Weight gain, feed intake and FCR were measured for starter and grower periods. The lightening schedule was $23 \mathrm{~h}$ light and $1 \mathrm{~h}$ darkness at $32^{\circ} \mathrm{C}$ in first day and subsequently reduced $3^{\circ} \mathrm{C}$ in each week until third week. At 42 days of age 3 birds per each replicate were randomly selected and slaughtered and carcass traits plus organelle weights were measured. All data were analyzed using GLM procedure of SAS software (2004). Duncan's Multiple Range Test was used for comparison of means $(\mathrm{P}<0.05)$.

\section{Results and Discussion}

The effects of thymus, licorice, thymus + licorice, and enzyme diets on performance traits, carcass traits and related immune organelles are shown in Table 1 and Table 2.

According to the results, performance traits including feed intake, gain and feed intake, carcass traits including dressing percentage and carcass parts such as breast and leg accompany with internal organs and related immune organelles such as burse and spleen weight in herbal medicine and enzyme supplemented diets were improved significantly than control diet $(\mathrm{P}<0.05)$. Internal organs such as abdominal fat and liver weight as indicators of lipogenesis rate were decreased in herbal medicine diets than control or enzyme supplemented diet

Table 1. Effect of different diets on performance traits of broilers.

\begin{tabular}{|c|c|c|c|c|c|c|}
\hline Treatments & Control & $\mathrm{T}$ & $\mathrm{L}$ & $\mathrm{TL}$ & $\mathrm{E}$ & SEM \\
\hline \multicolumn{7}{|c|}{ Starter (1 - 21 day) } \\
\hline Feed Intake (g/bird) & $62.2^{\mathrm{a}}$ & $60.6^{\mathrm{b}}$ & $60.7^{\mathrm{b}}$ & $61.5^{\mathrm{ab}}$ & $61.6^{\mathrm{ab}}$ & 1.22 \\
\hline Gain (g/bird) & $44^{\mathrm{b}}$ & $45.6^{\mathrm{ab}}$ & $44.8^{\mathrm{ab}}$ & $45.9^{\mathrm{a}}$ & $45.9^{\mathrm{a}}$ & 0.25 \\
\hline FCR $(g / g)$ & $1.42^{\mathrm{a}}$ & $1.33^{\mathrm{b}}$ & $1.36^{\mathrm{b}}$ & $1.34^{\mathrm{b}}$ & $1.34^{\mathrm{b}}$ & 0.04 \\
\hline \multicolumn{7}{|c|}{ Grower (22 - 42 day) } \\
\hline Feed Intake (g/bird) & $175.6^{\mathrm{a}}$ & $174.4^{\mathrm{a}}$ & $169.9^{b}$ & $171.5^{\mathrm{ab}}$ & $170.3^{\mathrm{ab}}$ & 2.22 \\
\hline Gain (g/bird) & $98.1^{\mathrm{a}}$ & $99.7^{\mathrm{a}}$ & $92.3^{\mathrm{c}}$ & $95.4^{\mathrm{b}}$ & $99.8^{\mathrm{a}}$ & 1.11 \\
\hline $\mathrm{FCR}(\mathrm{g} / \mathrm{g})$ & $1.79^{\mathrm{ab}}$ & $1.74^{\mathrm{ab}}$ & $1.84^{\mathrm{a}}$ & $1.80^{\mathrm{a}}$ & $1.70^{\mathrm{b}}$ & 0.06 \\
\hline \multicolumn{7}{|c|}{ Total Period ( 1 - 42 day) } \\
\hline Feed Intake (g/bird) & $118.3^{\mathrm{b}}$ & $117.7^{\mathrm{b}}$ & $115.8^{\mathrm{b}}$ & $123.3^{\mathrm{a}}$ & $116.7^{\mathrm{b}}$ & 2.10 \\
\hline Gain (g/bird) & $70.4^{\mathrm{a}}$ & $72.8^{\mathrm{a}}$ & $69.4^{c}$ & $71.7^{\mathrm{b}}$ & $72.5^{\mathrm{a}}$ & 1.46 \\
\hline FCR $(\mathrm{g} / \mathrm{g})$ & $1.70^{\mathrm{ab}}$ & $1.61^{\mathrm{b}}$ & $1.70^{\mathrm{ab}}$ & $1.73^{\mathrm{a}}$ & $1.61^{\mathrm{b}}$ & 0.07 \\
\hline
\end{tabular}

Notes: 1) T, L, TL, and E are Thymus, Licorice, Thymus + Licorice, and Enzyme treatments. 2) Means with different superscript letters significantly different at level of 0.05 . 
Table 2. Effect of different diets on carcass traits, internal organs and related immune organelles of broilers.

\begin{tabular}{cccccccc}
\hline Treatments & DP & Breast & Leg & AF & Liver & Burse & Spleen \\
\hline Control & $68.43^{\mathrm{b}}$ & $42.60^{\mathrm{a}}$ & $30.33^{\mathrm{a}}$ & $2.74^{\mathrm{a}}$ & $4.08^{\mathrm{a}}$ & $0.14^{\mathrm{b}}$ & $0.15^{\mathrm{b}}$ \\
$\mathrm{T}$ & $68.74^{\mathrm{b}}$ & $41.64^{\mathrm{b}}$ & $29.10^{\mathrm{b}}$ & $2.24^{\mathrm{b}}$ & $3.46^{\mathrm{b}}$ & $0.15^{\mathrm{b}}$ & $0.15^{\mathrm{b}}$ \\
$\mathrm{L}$ & $70.03^{\mathrm{a}}$ & $41.75^{\mathrm{b}}$ & $30.37^{\mathrm{a}}$ & $2.58^{\mathrm{ab}}$ & $3.70^{\mathrm{ab}}$ & $0.15^{\mathrm{b}}$ & $0.16^{\mathrm{b}}$ \\
TL & $70.73^{\mathrm{a}}$ & $42.35^{\mathrm{a}}$ & $30.04^{\mathrm{a}}$ & $1.94^{\mathrm{c}}$ & $3.27^{\mathrm{b}}$ & $0.18^{\mathrm{a}}$ & $0.19^{\mathrm{a}}$ \\
E & $70.52^{\mathrm{a}}$ & $42.16^{\mathrm{a}}$ & $30.95^{\mathrm{a}}$ & $2.01^{\mathrm{c}}$ & $3.92^{\mathrm{a}}$ & $0.14^{\mathrm{b}}$ & $0.16^{\mathrm{b}}$ \\
SEM & 0.65 & 0.46 & 0.35 & 0.05 & 0.11 & 0.01 & 0.01 \\
\hline
\end{tabular}

Notes: 1) T, L, TL, and E are Thymus, Licorice, Thymus + Licorice, and Enzyme treatments. 2) DP: Dressing Percentage, AF: Abdominal Fat. 3) Means with different superscript letters significantly different at level of 0.05 .

significantly $(\mathrm{P}<0.05)$. Immune organs such as burse and spleen weight as indicators of immune situation were increased in mixed herbal medicine diet than other treatments significantly $(\mathrm{P}<0.05)$.

These findings indicated that thyme and licorice singly or in combination as organic herbal medicine can affect performance, carcass and immune characteristics. These effects are positive and improved the efficiency of feed intake and growth, also increased the carcass part weights and decreased the abdominal fat pad weight accompany with reducing the liver weight which per se indicated decreased lipogenesis rate in liver and uptake the fat by this organ. Also improving the weight of immune organelles such as burse and spleen indicates that herbal medicines can promote the immune situation and efficacy of health and livability. These findings are in line with other relevant research reports [2] [10]. Increasing immune organ weights induced by herbal medicine metabolites such as phenolic compounds and glycyrrhizic acid in thyme and licorice well defined [7] [8]. These compounds have promoting effects on gastrointestinal tract and immune system to improve growth and health characteristics of birds [7] [8] [11]. All of data comprised simultaneously with a strong common feed additive to test and screen the results with a good criterion as positive control in addition to negative control or corn-soy based diet without any additives.

\section{References}

[1] Kalantar, M., Salary, J., Nouri Sanami, M., Khojastekey, M. and Hemati Matin, H.R. (2014) Dietary Supplementation of Sillybum marianum and Curcuma spp. on Health Characteristics and Broiler Chicken Performance. Global Journal of Animal Scientific Research, 2, 58-63.

[2] Hashemi, S.R. and Davoodi, H. (2010) Phytogenics as New Class of Feed Additive in Poultry Industry. Journal of Animal and Veterinary Advances, 9, 2295-2304. https://doi.org/10.3923/javaa.2010.2295.2304

[3] Sarica, S., Ciftci, A., Demir, E., Kilic, K. and Yildirim, Y. (2005) Use of an Antibiotic Growth Promoter and Two Herbal Natural Feed Additives with and without Exogenous Enzymes in Wheat Based Broiler Diets. South African Journal of Animal 
Science, 35, 61-72.

[4] Grashorn, M.A. (2010) Use of Phytobiotics in Broiler Nutrition-An Alternative to in Feed Antibiotics? Journal of Animal and Feed Sciences, 19, 338-347. https://doi.org/10.22358/jafs/66297/2010

[5] Zalari, I. and Ferket, P.R. (1990) The Effect of Enzyme Supplementation of Corn-Soy Diets on the Performance of Broilers. Poultry Science, 69, 139.

[6] El-Ghousein, S.S. and Al-Beitawi, N.A. (2009) The Effect of Feeding of Crushed Thyme (Thymus valgaris L) on Growth, Blood Constituents, Gastrointestinal Tract and Carcass Characteristics of Broiler Chickens. The Journal of Poultry Science, 46, 100-104. https://doi.org/10.2141/jpsa.46.100

[7] Toghyani, M., Tohidi, M., Gheisari, A.B. and Tabeidian, S.A. (2010) Performance, Immunity, Serum Biochemical and Hematological Parameters in Broiler Chicks Fed Dietary Thyme as Alternative for an Antibiotic Growth Promoter. African Journal of Biotechnology, 9, 6819-6825.

[8] Najafi, P. and Torki, M. (2010) Performance, Blood Metabolites and ImmuneCompetence of Broiler Chicks Fed Diets Included Essential Oils of Medicinal Herbs. Journal of Animal and Veterinary Advances, 9, 1164-1168.

https://doi.org/10.3923/javaa.2010.1164.1168

[9] NRC (National Research Council) (1994) Nutrient Requirements of Poultry. National Academy of Science, Washington DC.

[10] Bolukbasi, S.C., Kuddusi, M. and Kaynar, O. (2008) The Effect of Feeding Thyme, Sage and Rosemary Oil on Laying Hen Performance, Cholesterol and Some Proteins Ratio of Egg Yolk and Escherchia coli Count in Faces. Archiv fur Geflugelkunde, 72, 231-237.

[11] Rhee, K.J., Jasper, P.J., Sethupathi, P., Shanmugan, N., Lanning, D. and Lanning, K.L. (2005) Positive Selection of Peripherial B Cell Repertoire in Gut-Associated Lymphoid Tissues. The Journal of Experimental Medicine, 201, 55-62. https://doi.org/10.1084/jem.20041849

\section{Scientific Research Publishing}

\section{Submit or recommend next manuscript to SCIRP and we will provide best} service for you:

Accepting pre-submission inquiries through Email, Facebook, LinkedIn, Twitter, etc. A wide selection of journals (inclusive of 9 subjects, more than 200 journals)

Providing 24-hour high-quality service

User-friendly online submission system

Fair and swift peer-review system

Efficient typesetting and proofreading procedure

Display of the result of downloads and visits, as well as the number of cited articles

Maximum dissemination of your research work

Submit your manuscript at: http://papersubmission.scirp.org/

Or contact ojas@scirp.org 